\title{
UM ELO ENTRE VIVOS E MORTOS - OS SÍMBOLOS E RITOS NOS CEMITÉRIOS DE SERROLÂNDIA
}

\author{
Bruna Cordeiro SALDANHA ${ }^{1}$
}

\begin{abstract}
Resumo
Este trabalho tem o objetivo de discutir os elementos que representam as manifestações culturais e religiosas a partir dos campos fúnebres em Serrolândia-BA, cidade composta por três cemitérios, sendo dois públicos municipais e um protestante. A pesquisa é parte da dissertação de mestrado e discute as diferentes linguagens contidas nos ambientes fúnebres a partir da cultura e religiosidade social, uma vez que as representações culturais presentes nas necrópoles refletem por um lado, os modos de viver das pessoas, e por outro, a interpretação que os indivíduos têm sobre a morte. Assim, busca-se traçar um elo entre o mundo dos vivos com o mundo dos mortos, a fim de apresentar os elementos contextuais das constituições tumulares, os seus componentes simbólicos e materiais, as expressões culturais e as manifestações sociais. Deste modo, adotamos estratégias metodologicamente voltadas para a abordagem qualitativa, feitas a partir da observação, da empiria e das fotografias, com o intuito de entender as motivações culturais, sociais e religiosas expostas nas paisagens sepulcrais.
\end{abstract}

Palavras-Chave: Cemitério; morte; símbolo; cultura; crenças.

\section{A LINK BETWEEN THE LIVING AND THE DEAD - SYMBOLS AND RITES IN SERROLANDIA CEMETERIES}

\begin{abstract}
This work aims to discuss the elements that represent cultural and religious manifestations from the funeral fields in Serrolândia-BA, a city composed of three cemeteries, two of which are public and one Protestant. The research is part the master's thesis work and discusses the different languages contained in funeral environments based on culture and social religiosity, since the cultural representations present in necropolises reflect, on the one hand, people's ways of living, and on the other, the interpretation that certain individuals have about death. Thus, we seek to draw a link between the world of the living and the world of the dead, in order to understand and present the contextual elements of the tomb constitutions, their symbolic and material components, cultural expressions and social manifestations from the countryside. religious. In this way, we adopt strategies that are methodologically oriented towards a qualitative approach, made from observation, empiricism and photographs, in order to understand the cultural, social and religious motivations exposed in the sepulchral landscapes.
\end{abstract}

Key words: Cemetery; death; symbol; culture; beliefs.

\footnotetext{
${ }^{1}$ Mestra pelo Programa de Pós-Graduação em Geografia da Universidade Federal do Rio Grande
} do Norte - UFRN. E-mail: brunasaldanha1@hotmail.com 


\section{UN ENLACE ENTRE LA VIDA Y LOS MUERTOS - SÍMBOLOS Y RITOS EN LOS CEMENTERIOS DE SERROLANDIA}

\section{Resumen}

Este trabajo tiene como objetivo discutir los elementos que representan las manifestaciones culturales y religiosas de los campos funerarios de SerrolândiaBA, ciudad compuesta por tres cementerios, dos de ellos públicos y uno protestante. La investigación forma parte del trabajo de tesis de maestría y discute los diferentes lenguajes contenidos en los ambientes funerarios basados en la cultura y la religiosidad social, ya que las representaciones culturales presentes en las necrópolis reflejan, por un lado, las formas de vida de las personas, y por otro, la interpretación. que ciertos individuos tienen sobre la muerte. Así, buscamos trazar un vínculo entre el mundo de los vivos y el mundo de los muertos, con el fin de comprender y presentar los elementos contextuales de las constituciones sepulcrales, sus componentes simbólicos y materiales, expresiones culturales y manifestaciones sociales del campo. religioso. De esta manera, adoptamos estrategias que se orientan metodológicamente hacia un enfoque cualitativo, a partir de la observación, el empirismo y la fotografía, para comprender las motivaciones culturales, sociales y religiosas expuestas en los paisajes sepulcrales.

Palabras clave: cementerio; muerte; símbolo; cultura; creencias.

\section{INTRODUÇÃO}

Dentro dos espaços mortuários, a morte é exercida em suas mais variadas interpretações, pois reflete as expressões culturais de um povo e a multiplicação das relações sociais. Aliás, referir-se à morte é atestar a nossa própria existência como ser vivo. A morte é, inclusive, a característica mais intrínseca à nossa humanidade.

Por meio da consciência da morte, o homem começa a vivenciar uma relação de entendimento sobre si mesmo, partindo da percepção de que sua humanidade não é capaz de dominar a finitude, já que esta ultrapassa os limites da própria existência e da razão, estando em um plano transcendental, o que desafia as mais diferentes culturas.

Giacoia Júnior (2005) diz que o modo com que a sociedade se posiciona perante a morte e os seus mortos demonstra um papel decisivo na constituição e na manutenção de sua própria identidade coletiva. Assim, os espaços cemiteriais acabam por guardar "viva" a memória dos que morreram e hoje descansam na "cidade dos mortos", trazendo consigo a certeza do repouso perpétuo e a evidência de um fato incontestável: a finitude humana. 
Deste modo, a fim de analisar as experiências individuais e coletivas nos cemitérios, adentramos no universo fenomênico da morte para compreendermos a reprodução social experimentada nos seus espaços fúnebres.

A pesquisa é parte resultante do trabalho de dissertação de mestrado e tem como objetivo identificar os elementos que representam os componentes simbólicos, as manifestações culturais, religiosas e sociais a partir dos campos fúnebres em Serrolândia-BA, cidade interiorana, composta por três cemitérios, sendo dois públicos municipais e um protestante, privado².

Localizado no território de identidade do Piemonte da Diamantina3, norte da Bahia, o município de Serrolândia tem sua população estimada em 13.347 habitantes, sendo 6.000 residentes da sede e os demais dos povoados e da zona rural.4

Vale salientar que o estado da Bahia em conjunto com a Secretaria Estadual de Cultura (SECULT), instituiu 27 (vinte e sete) territórios de identidade 5 abrangendo todo o estado, com o intuito de descentralizar os recursos para a cultura, expressando a sua importância como estratégia de desenvolvimento no estado, para que cada grupo decidisse, com base no sentimento de pertencimento, as prioridades para a sua região. Isso se deve as pluralidades culturais/sociais inerentes ao território baiano.

O mapa apresentado a seguir (figura 1), demonstra a divisão espacial dos cemitérios em Serrolândia, explicitando a cidade, o estado e sua configuração espacial:

\footnotetext{
${ }^{2}$ Serrolândia tem em seu espaço o Cemitério Municipal Anízia Carneiro de Magalhães (primeiro cemitério municipal), o Cemitério Shalom (protestante, sendo o segundo cemitério do município), e o Cemitério Jardim das Acácias (terceiro cemitério do município, construído após a lotação do primeiro cemitério municipal).

$3 \mathrm{Na}$ Bahia vem sendo aplicadas intervenções em torno da descentralização de serviços e recursos, através do processo de territorialização da cultura, considerando aspectos geográficos, sociais, econômicos e culturais em suas particularidades e comuns a cada território.

4 IBGE, Instituto Brasileiro de Geografia e Estatística. Dados populacionais. Disponível em: www.ibge.gov.br Acesso em 22 de janeiro de 2019.

5 Com o objetivo de identificar prioridades temáticas definidas a partir da realidade local, possibilitando o desenvolvimento equilibrado e sustentável entre as regiões, o Governo da Bahia passou a reconhecer a existência de 27 Territórios de Identidade, constituídos a partir da especificidade de cada região. Sua metodologia foi desenvolvida com base no sentimento de pertencimento, onde as comunidades, através de suas representações, foram convidadas a opinar. Disponível em: http://www.seplan.ba.gov.br/. Acesso em 10 de janeiro de 2019.
} 
Figura 1 - Mapa de localização dos três Cemitérios em Serrolândia-BA

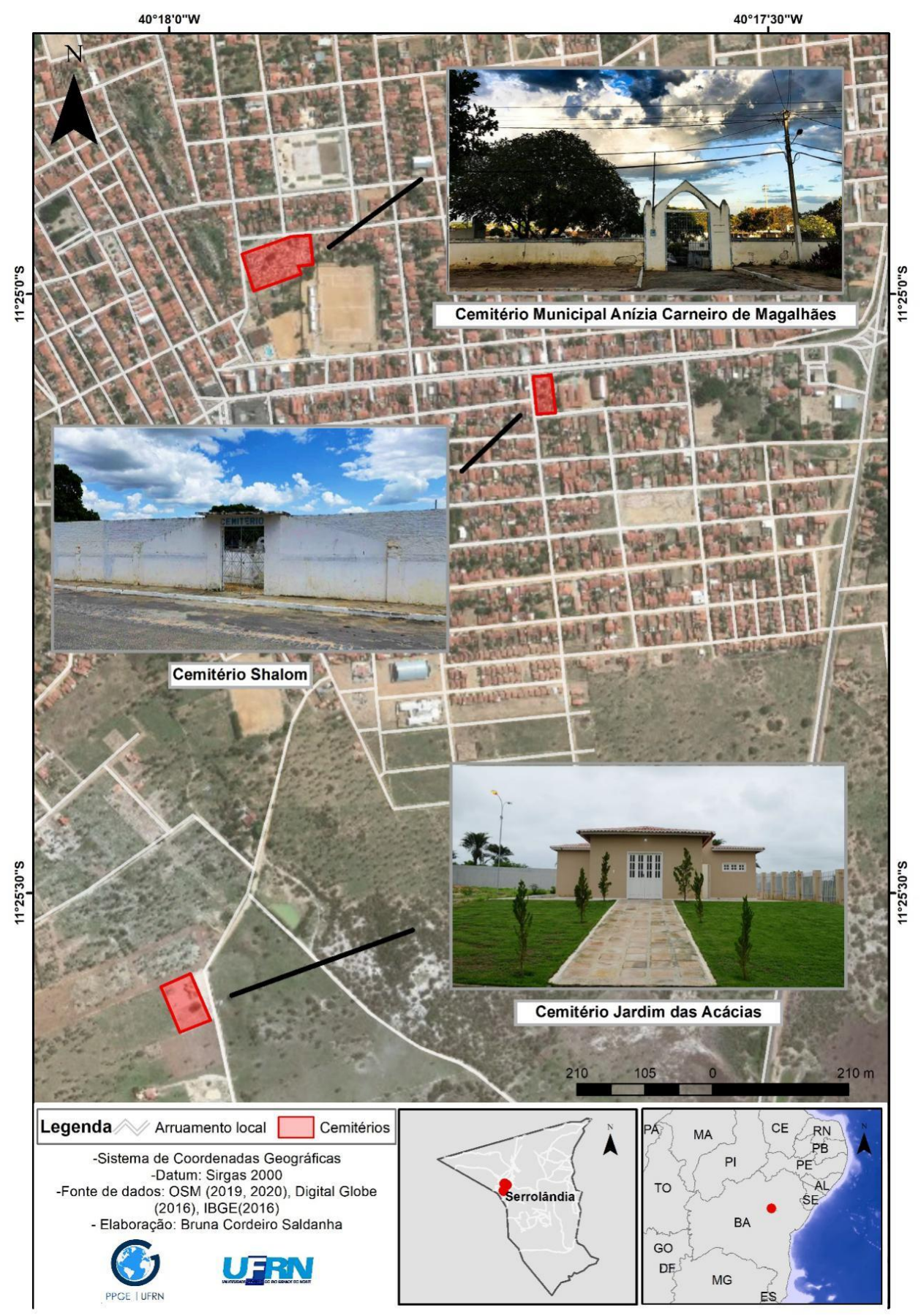

Fonte: Saldanha, 2020.

Nos propomos a analisar os simbolismos existentes nos cemitérios, apresentando a relação de crenças e culturas que são expressadas como resposta à morte. Neste sentido, nos dispomos de fotografias para ilustrar os símbolos e estruturações tumulares dos três cemitérios aludidos. 
É importante destacar que as intencionalidades da pesquisa partem de um cenário cultural, já que a morte e os cemitérios provocam uma vivência social e expressam diferentes visões de apropriação religiosa e social, enquadrando-se, desta forma, no campo da Geografia Cultural.

Para alcançarmos os objetivos propostos, adentramos em estratégias metodologicamente voltadas para a abordagem qualitativa, uma vez que o contexto em que se insere a pesquisa são subjetivos, feitas a partir da observação, da empiria e das fotografias, com o intuito de entender as motivações culturais, sociais e religiosas expostas nas paisagens sepulcrais.

Deste modo, utilizamos de alguns dispositivos de pesquisa que foram essenciais para a concretização da pesquisa, a exemplo dos trabalhos de campo, que resultaram na obtenção de entrevistas e fotografias dos três cemitérios, nos possibilitando fazer um comparativo dos aspectos religiosos-doutrinários e culturais entre os ambientes mortuários a partir dos símbolos e das morfologias tumulares, bem como as pesquisas e leituras de livros, teses, dissertações e artigos, que nos ofereceram subsídios teórico-metodológicos para estabelecer uma relação do objeto de estudo com as abordagens teóricas.

Assim, compreendemos que tais caminhos servem de auxílio para o entendimento das simbologias que emergiram do campo religioso e cultural e se expressam culturalmente de diferentes formas no espaço serrolandense, pois adentrar no universo mortuário nos trouxe a capacidade de visualizar as construções culturais que se evocam ao se pensar habitar em um plano por nós desconhecido, uma vez que olhar para os espaços da morte e suas manifestações religiosas nos condiciona a vivenciar um pouco do temor e a sacralidade com que os homens lidam com a finitude.

\section{UM ELO DE MEMÓRIA: ÀS MANIFESTAÇÕES NOS ESPAÇOS CEMITERIAIS ENQUANTO EXPRESSÕES CULTURAIS}

Desde os primórdios da humanidade, há indicativos e relatos da utilização de símbolos, tanto no cotidiano social, como em rituais específicos. Quando analisamos por uma perspectiva de ambiente cemiterial, o uso de símbolos se faz recorrente por expressar a dualidade do sujeito e objeto, tendo em vista as relações que a sociedade faz ao manifestar, individual ou coletivamente, as suas interpretações de vida. Para Bellomo (2000, p. 121) o 
símbolo é entendido "não como objeto concreto, e sim, com o significado que este pode trazer, isto é, a transmissão de culturas e valores sociais".

Assim, se concebe que a simbologia cemiterial tem por fundamento a transmissão e expressão cultural e o estabelecimento das relações sociais, uma vez que a individualização das sepulturas e as escolhas retratadas em suas artes tumulares testemunham o anseio de perpetuar a identidade e a memória dos mortos, que objetivam transmitir os valores culturais para os que ficaram, pois as características e elementos simbólicos servem de conforto para os próprios vivos, que fazem esse "elo de memória" com a intenção de encontrarem refrigério na visita ao morto que está resguardado pelos símbolos.

Para Catroga (1999, p.55) "a importância dada à consagração monumental dos seus mortos revela a densidade da sua assunção como herdeiros de uma linhagem: cada tumba é a fixação de um morto, [...] é, a expressão de uma individualidade." Na realidade, o medo do esquecimento gera a necessidade dos registros em diferentes ambientes ou situações, "pelos traços, arquivos, museus, cemitérios, coleções, festas, comemorações, aniversários, [...], santuários, associações; processos que dão ilusões de eternidade” (FÉLIX, 2002, p.53). Surge, então, a emergência em conservar a memória do morto no cotidiano da vida.

Através das simbologias representadas nas sepulturas, é possível compreender as significações que os vivos têm para com os seus mortos, buscando perpassar as particularidades dos que se foram para, assim, a memória do defunto permanecer viva no imaginário social, como uma espécie de busca da dignidade perante a morte.

Percebemos que as tipologias tumulares são meios que a sociedade encontra para demonstrar os sentimentos que se têm sobre a morte, sempre com o objetivo de cristalizar a memória do falecido, a fim de manter viva a sua identidade. Essa perpetuação da memória se reverbera por um viés também coletivo, pois a identidade cultural se expressa por meio da dominação simbólica que está vinculada às manifestações nos espaços cemiteriais, como nos afirma Le Goff (1996, p.476): "a memória é um elemento essencial do que se costuma chamar identidade, individual ou coletiva, cuja busca é uma das atividades fundamentais dos indivíduos e das sociedades de hoje.” 
Em Serrolândia, a representação religiosa como em qualquer necrópole se faz presente de distintas formas. O contexto econômico e religioso são as principais influências para a produção simbólica, especialmente no que diz respeito às tipologias das sepulturas e dos materiais utilizados.

A variedade de simbolismos presentes nos locais tem o predomínio de arquétipos de influências religiosas de cunho cristão, pois a população serrolandense é, predominantemente, cristianizada e católica. Por isso, a estética cristã carrega o que o Didi-Huberman chama de melancolia, uma vez que "o homem da crença prefere esvaziar os túmulos de suas carnes putrecentes, [...] para enchê-los de imagens corporais sublimes, feitas para confortar e informar nossas memórias, nossos temores e nossos desejos [...]” (ARAÚJO, 2014, p. 84).

Consideramos que isso se deve a uma herança histórica, pois em determinado período acreditava-se que era fundamental o ser humano ser enterrado em local sagrado. Como a igreja era o ambiente onde as pessoas se sentiam mais próximas à salvação, era considerada a porta de entrada para o Paraíso. Assim, "o corpo era confiado à Igreja. Pouco importava o que faria com ele, contanto que conservasse dentro de seus limites sagrados". (ARIÈS, 1989, p. 42). Além disso, os vivos também estariam mais próximos dos seus mortos, evitando o esquecimento.

Com o fim dos sepultamentos em igrejas, os símbolos religiosos foram transferidos para os cemitérios, para remeter o que estava dentro das realidades sagradas, como as cruzes, velas, flores, imagens etc., Isso se dá porque, segundo Barboza (2013), o homem teria a tendência a remeter para o campo sagrado tudo o que consideraria importante para a reprodução social.

A partir das configurações dos rituais da morte, compreendemos que são nos espaços cemiteriais que as representações e as relações sociais se corporificam, pois suas composições materiais e simbólicas refletem a cultura e a realidade social de um povo, tendo em vista que, ali, no ambiente fúnebre, o "vivo" está diretamente ligado ao morto. Para Gil Filho (2002), o espaço de representação se refere a um âmbito da experiência da espacialidade que é proveniente da contextualização do sujeito. Assim, refere-se a um espaço simbólico que perpassa o espaço visível e nos idealiza/projeta no mundo. Posto isto, consideramos os cemitérios como espaços de representações. 
Em Merleau-Ponty (1994, p. 258) "o espaço não é um meio contextual (real e lógico) sobre o qual as coisas estão colocadas, mas sim o meio pelo qual é possível a disposição das coisas.” Desta forma, é possível afirmar que são a partir das conexões e das experiências espaciais focadas no sujeito que a percepção do indivíduo se estabelece no espaço e, assim, se organiza.

Quando analisamos as morfologias dos cemitérios, percebemos que nele estão instaladas as representações sagradas e religiosas em suas estruturas tumulares, que se estabelecem a partir dos desejos e das manifestações do imaginário individual ou coletivo dos vivos, visto que, nos espaços da morte, as representações se revelam frente aos aspectos sociais e aos elementos simbólicos e religiosos, expressando o meio social com sua cultura, pois, como diz Gil Filho (2002, p. 56), "são os atores sociais que, através de parâmetros coletivos, atribuem sentidos e significados espaciais, revestindo o espaço de uma natureza social."

Portanto, entendemos que os espaços e as representações sociais nos cemitérios não somente estão envoltos aos atributos e exteriorizações dos componentes econômicos, mas estão também imbuídos de traços e valores afetivos ligados à religiosidade, que seria o que Cassirer chama de espaço mítico, que é o espaço da esfera afetiva, sentimental, da atmosfera que envolve os lugares com seus valores próprios (CASSIRER, 2004 [1925]). Para Gil Filho (2002, p. 57), "a visão mítica do espaço é a reprodução de algo que em si mesmo não é espacial.

Levando em conta a discussão realizada no sentido das representações espaciais e simbólicas, se faz importante apontar a relevância da reflexão para os debates geográficos, pois o geógrafo tende a buscar, a partir das experiencias individuais ou sociais, a manifestação do Sagrado nos espaços, já que, como nos aponta Rosendahl (1996), a experiência da religião e da fé através de uma análise geográfica é particularmente importante pelo tempo e espaço em que ela ocorre ao se pensar sobre a ação missionária de expansão de ideias e de subordinações simbólicas.

Segundo a autora "o estudo geográfico da religião dá a razão humana, (...) uma vez que a geografia e a religião se encontram através da dimensão espacial, uma analisa o espaço, e a outra, como fenômeno cultural, ocorre espacialmente." (ROSENDAHL, 1996, p. 11). Ambas operam de diferentes 
modos no espaço: seja através da normatização da religião em relação aos homens (no espaço), seja pelo saber que a ciência geográfica possibilita através dos modos de atuação nesse espaço.

Os cemitérios, por exemplo, estão compreendidos nessa dimensão sagrada e espacial, pois é um local que abrange em sua extensão fenômenos culturais, religiosos e sociais, desde os rituais fúnebres coletivos, a manifestações individuais de crenças sagradas, no uso de símbolos expostos que são propriamente voltados ao misticismo religioso, porque, como nos diz Piacesk e Bellomo, "a imagem da morte e suas representações são de ordem social, petrificadas pela experiência da idade, classe religião e cultura" (PIACESK; BELLOMO, 2006 p. 16).

Assim, compreendemos que as exteriorizações morfológicas caracterizadas por símbolos e morfologias tumulares dos cemitérios de Serrolândia é resultado de uma influência cultural, extremamente marcada pela religiosidade cristianizada, como veremos na discussão a seguir.

\section{UMA RELAÇÃO DE CRENÇAS E CULTURAS COMO RESPOSTAS À MORTE - OS SIMBOLISMOS NOS CEMITÉRIOS DE SERROLÂNDIA}

Em relação aos cemitérios de Serrolândia, fomos a campo para analisar as suas morfologias e suas manifestações culturais e percebemos que, em ambos os espaços, há certa similaridade no que se refere aos adornos e monumentalizações em toda a sua estrutura física, desde as edificações tumulares, aos simbolismos postos em seus espaços. No cemitério municipal Anízia Carneiro de Magalhães (primeiro cemitério municipal da cidade), há uma especificidade cultural que difere dos outros, pois encontramos a presença de simbolismos que mesclam pelo viés de um sincretismo religioso afro-brasileiro.

Nos três espaços fúnebres, entretanto, há um padrão morfológico hierofânico, de jazigos que remetem a edificações de santuários, que se caracteriza como uma herança das antigas configurações sepulcrais, onde os mortos eram enterrados nas igrejas. Até mesmo a edificação tumular é partindo da perspectiva de um templo sagrado. Esses símbolos seriam uma via de distanciamento da condenação.

São construções simples e pouco dispendiosas, que refletem as condições econômicas da população. No caso dos sujeitos mais prósperos, há a feitura em 
monumentalizar e ornar o jazigo de modo a se destacar entre a sociedade do qual faz parte. Contudo, de maneira geral não se observa grandes detalhes artísticos, como esculturas de anjos, da Virgem Maria ou outros elementos, porque economicamente é inviável para grande parte da população.

Os mais abastados constroem os túmulos em mármore, com fotos do falecido ao lado de frases bíblicas ou frases de saudade, e os mais simples são construídos em azulejos ou até mesmo demarcados por um amontoado de terra com uma cruz fixada, indicando o nome do falecido e a data da morte, como os descritos na figura a seguir:

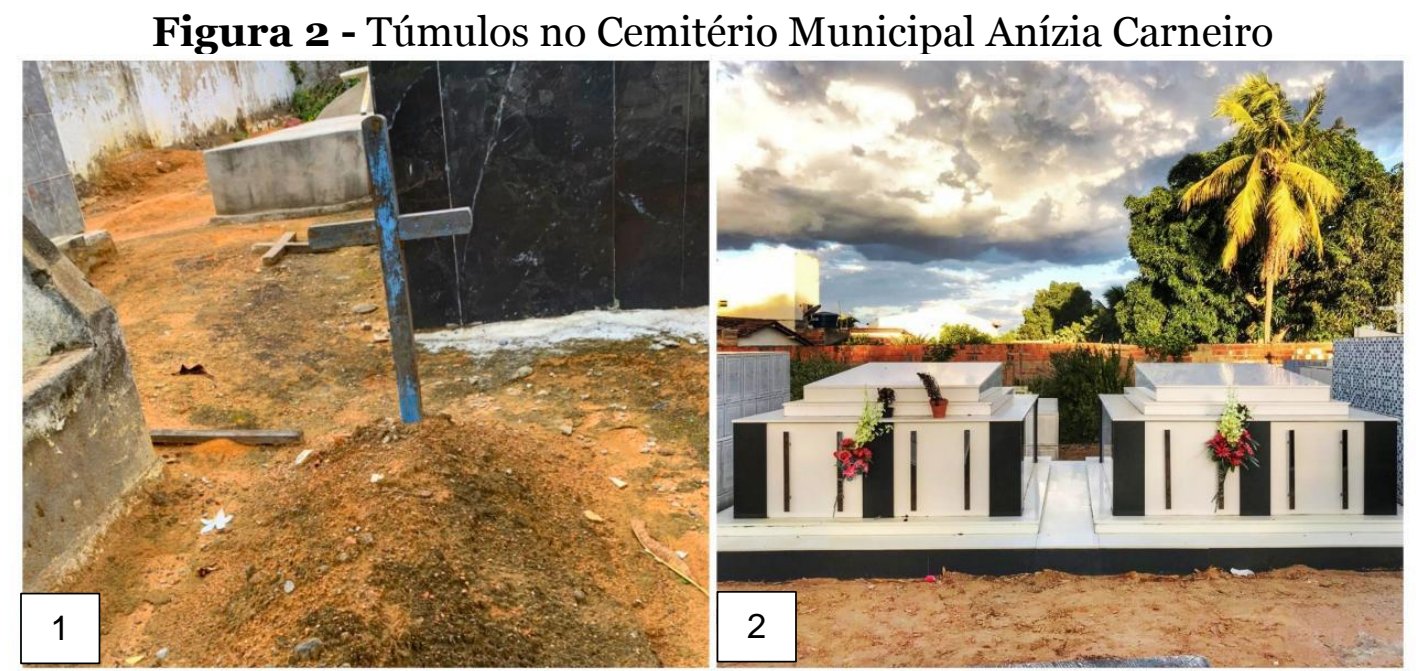

Fotografias: Saldanha, 2020.

Nas imagens da figura 2, apresentamos as contradições sociais entre os túmulos, fato muito comum de ser encontrado nas paisagens dos espaços funerários, visto que as tipografias tumulares refletem não somente a cultura popular e a religiosidade do povo, mas revelam-se também nas formas adequadas às condições econômicas da população, pois como nos diz Bellomo (2000, p.15): "os cemitérios reproduzem a geografia social das comunidades e definem as classes sociais".

No que tange às diferenças dessas edificações, percebemos as simbioses entre o mundo dos vivos e o mundo dos mortos, pois apesar da separação física, há uma coexistência de atitudes que são transmitidas pelos dois sentidos. Contudo, nessas desigualdades é possível identificar culto aos mortos comum a todos, ao reverenciarem seus falecidos e resguardarem a memória dos seus entes no "novo mundo", transformando o ambiente em um lugar de 
recolhimento, comoção e saudosismo, não eximindo o seu caráter sagrado, porque "o cemitério é concebido como um local de reprodução simbólica [...] das expectativas metafísicas. Este simbolismo é decorrente de uma ligação entre o culto dos mortos e a memória individual e coletiva" (URBAIN, 1978, p.85).

Do mesmo modo, ao analisar o Cemitério Shalom (protestante), percebemos que a estrutura segue um arquétipo similar ao católico. São jazigos modestos e sem muitos ornatos, seguindo a disposição das outras necrópoles que, em sua maioria, são feitas em azulejo ou cimento e alvenaria. Entretanto, na maior parte das construções não há utilização de aparatos de representações religiosas ou locais específicos para orações aos mortos, bem como o uso de velas e imagens. A decoração segue uma estrutura mais "limpa" e básica, mas em grande parte com a semelhança morfológica de igrejas, fato que parte de uma herança católica após a desvinculação da Igreja Católica com os processos mortuários.

Figura 31 - Paisagem fúnebre no Cemitério Shalom

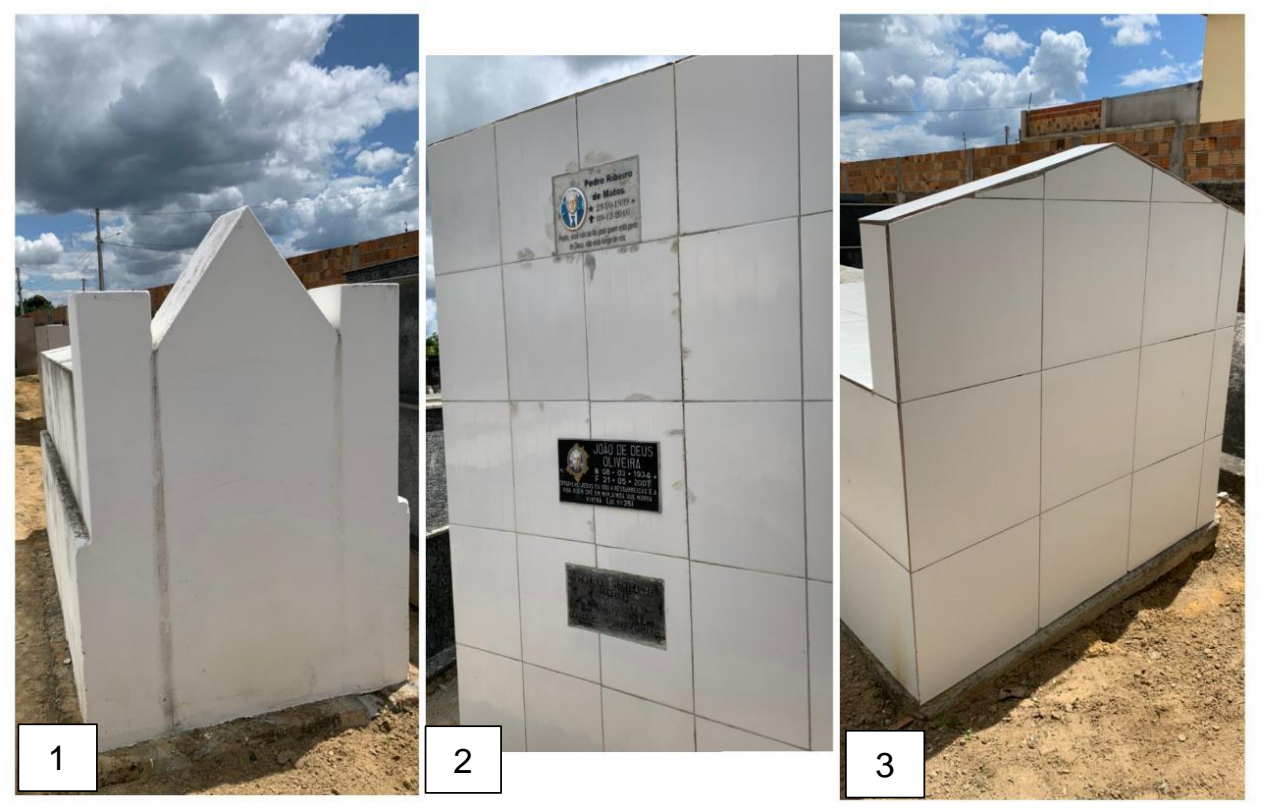

Fotografias: Saldanha, 2020.

Essa estruturação singela do cemitério protestante segue em conformidade com a sua doutrina, que proíbe o uso de imagens para quaisquer fins, pois a postura evangélica orienta total desprezo à rememoração de santos, cruzes ou outros tipos de imagens ou venerações. Para Cerveira (2012, p. 48) "a aversão evangélica histórica à imagem, uma teologia centrada no não-ser e uma 
pobreza litúrgica e simbólica, são apenas alguns aspectos da oposição a um "inimigo" com o qual se disputa a salvação das almas".

Cerveira não especifica qual seria o "inimigo" de disputa. No entanto, acreditamos ter relação com a Igreja Católica, que foi a principal adversária do protestantismo desde o início da Reforma, que, aliás, se deu em "protesto" aos dogmas católicos.

Entretanto, um adendo se faz oportuno quanto à simbologia tumular protestante no cemitério Shalom, pois em alguns dos seus cumes sepulcrais há a presença de cruzes fixadas no topo, como podemos observar nas imagens da figura 4:

Figura 42: Túmulos com símbolos da cruz no Cemitério Shalom

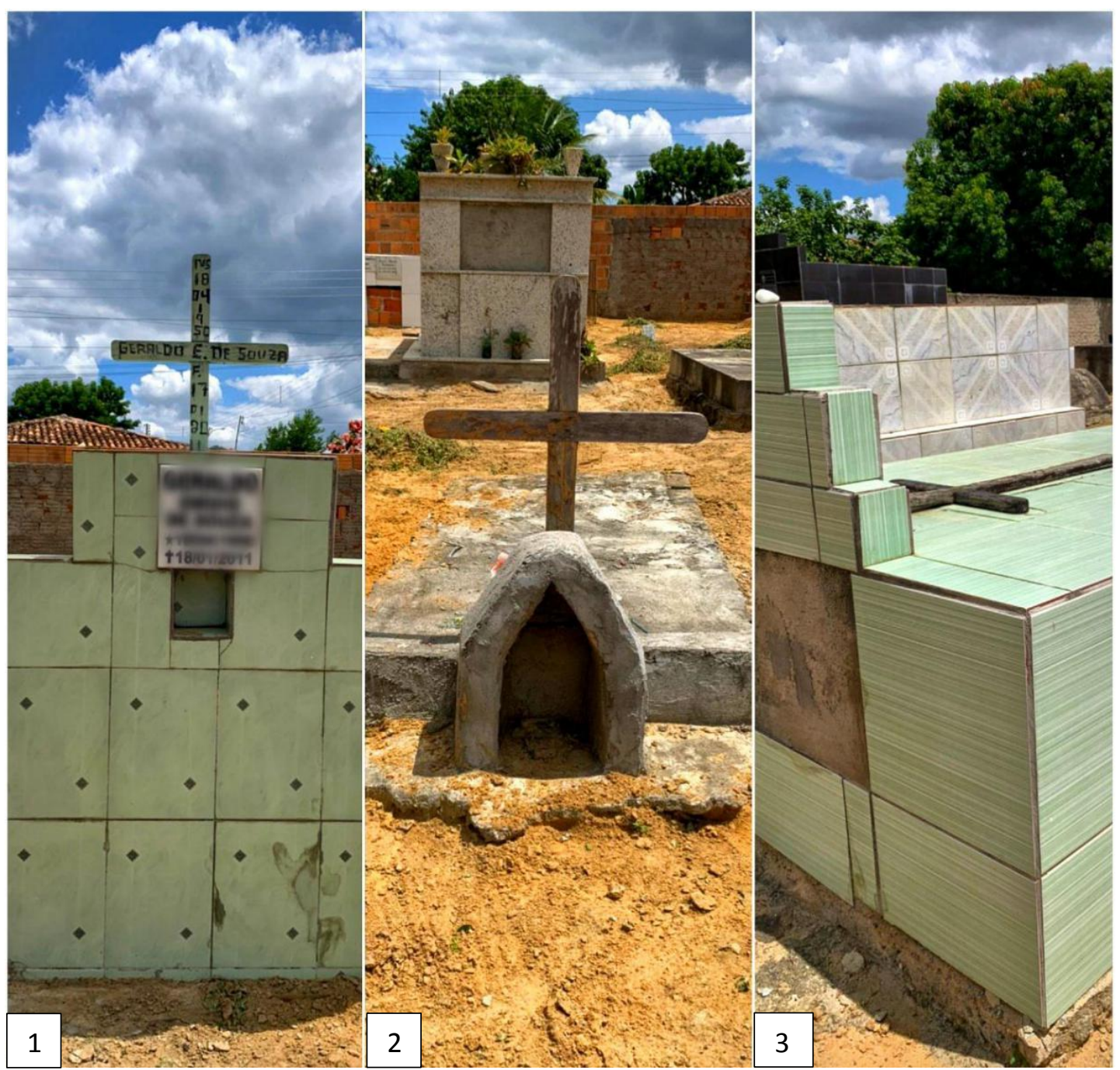

Fotografias: Saldanha, 2020. 
Embora em países da Europa e nos EUA o uso da cruz seja usual por parte de determinados segmentos evangélicos, no Brasil esses símbolos são repudiados pelo protestantismo, principalmente a cruz, por associarem à idolatria.

De acordo com Rios Júnior (2012, p. 156) a cruz para os protestantes "era considerada como sinal de fanatismo condenada com aspereza", pois o evangélico prioriza a fé interior, como nos afirma o pastor da Igreja Batista: "o protestante evangélico segue as Escrituras procurando ver na Palavra toda a orientação espiritual. A riqueza da sua fé é totalmente interior e sentimental."6

Para os protestantes, o foco simbólico da morte é a ideia de salvação, eximindo qualquer objeto ou simbolismo de culto ao morto. Essa premissa se reflete não somente nas paisagens cemiteriais, mas ecoa nas monumentalizações dos seus templos, porque, como afirma Rivera (2007, p. 53) isso é "herança da Reforma, que levou o protestantismo - com poucas exceções - a subestimar todos os objetos, símbolos sagrados e sacramentos."

Contudo, mesmo nessa aversão, é visível a influência que o catolicismo desempenhou na identidade coletiva da população serrolandense, pois não somente encontramos túmulos com cruzes fixadas, como também sepulturas com o espaço adequado para a instituição de velas, expressão simbólica também oriunda do catolicismo, como representa a imagem 2 da figura 4.

Acreditamos que essas ações são reflexo das influências que o catolicismo exerceu por tantos anos na formação identitária da população serrolandense, sobretudo porque foi, por muito tempo, o único segmento professado na localidade. Então, os comportamentos se refletiram também nas construções sepulcrais.

Muito embora exista algumas especificidades de simbologias católicas no cemitério dos crentes, de maneira geral não apresenta grande riqueza de atributos religiosos, pois com exceção de pequena parcela de cruzes, não encontramos demais adornos cristãos, a não ser as próprias sepulturas que remetem aos templos sagrados, como mencionado, tendo em vista o fortalecimento maior da doutrina embrenhar-se pelo campo das concepções salvacionistas.

${ }^{6}$ Entrevista com o ex-pastor da Igreja Batista de Serrolândia, realizada em 29 dezembro de 2018. 
Em análise ao cemitério católico, contudo, percebemos grande quantidade de imagens de santos e da Virgem Maria, expostas no interior de uma pequena capela existente no local, porque, para a doutrina católica, esses atributos sagrados auxiliam o fiel a se conectar com os mistérios da fé cristã, como meios de produzir a piedade e a devoção popular. No entanto, é possível perceber que, além de imagens unicamente católicas encontradas na capela, há a presença de um sincretismo religioso com as religiões de matriz africana.

Importante salientar que essas tipologias sincréticas introduzidas no cemitério não revelam um credo escancarado nas edificações tumulares, pois são postos pelo povo apenas nessa pequena capela de estrutura rudimentar, utilizada para orações aos mortos. Nela encontramos santos cultuados pelo catolicismo e que, no período colonial, eram reinterpretadas pelos negros de acordo aos seus orixás.

A capela é um local considerado por muitos como "sombrio", pois por ser antiga, há um acúmulo de objetos velhos e túrbidos, como santos sem cabeça, bonecas deformadas, restos de velas, caixotes, quadros e fotos de pessoas falecidas, além de imagens com feições disformes.

Pela tradição popular na cidade, têm-se que que após a morte do indivíduo, seus objetos sagrados são levados consigo à sua nova morada, neste caso o cemitério. Por isso, ao momento do enterro ou no dia de finados, os familiares levam os objetos memorialísticos de seus mortos e depositam na capela, como uma entrega ou "oferta" ao morto.

Além de santos unicamente católicos, diversas imagens, oratórios e símbolos sincretizados são encontrados no local, a exemplo de santos e colares utilizados nas religiões umbandistas e candomblecistas.

Câmara Cascudo define essa expressão coletiva popular como "santos do povo" pois são "santos regionais, irregulares iconicamente, mas consagrados pela confiança popular." (CASCUDO, 2001. p. 422.) Ou seja, diversos santos são consagrados e apossados por crenças populares, ao ponto de se tornar até difícil distinguir quem é quem nas devoções religiosas expostas. 
Figura 5 - Imagens situadas na capela do Cemitério Municipal Anízia Carneiro de Magalhães

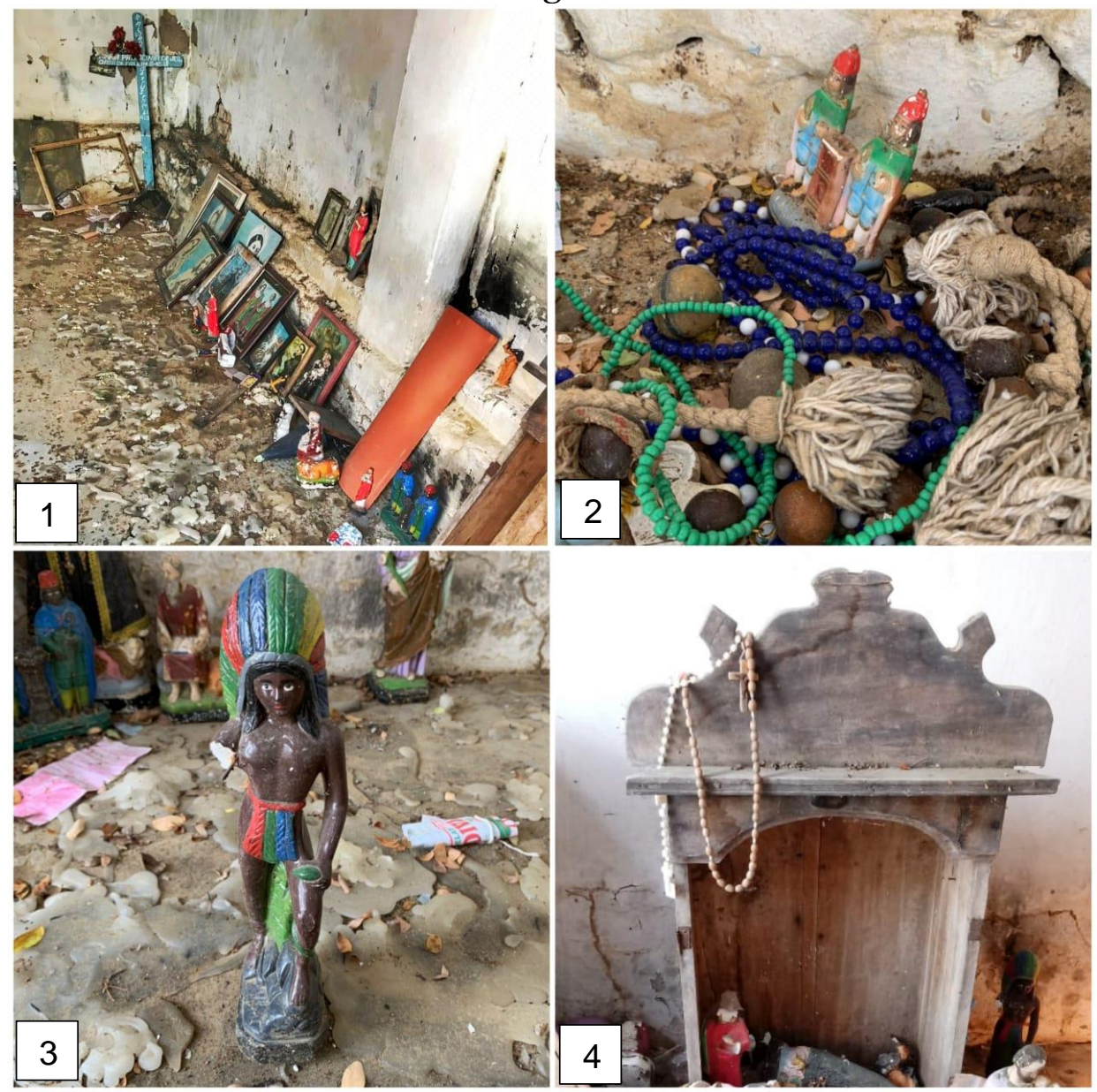

Fonte: Saldanha, 2020.

Como exposto nas imagens, os objetos e imagens são "jogados" ao chão da capela, aparentando falta de zelo com o sagrado. Contudo, os restos de velas na superfície e as inúmeras velas acesas no dia de finados demonstram que o local não foi esquecido pelos fiéis. Aliás, no dia dedicado aos mortos o espaço fica repleto de devotos e novas imagens são introduzidas no local.

Os símbolos encontrados na capela são predominantemente de cunho sagrado, seja ele católico ou representados com a intenção de manifestar a religiosidade de matriz africana. Isso porque em determinado período no Brasil, a devoção aos santos mesclava a doutrina católica com a prática religiosa vivida na "intimidade" de brancos, negros e índios. (PIMENTEL, 2012).

Entretanto, não podemos afirmar com veemência se os símbolos são, de fato, exteriorizações das religiões afro-brasileiras. Mas, supomos que as 
imagens e objetos coincidentes podem ser retrato de uma crença que está presente na cultura baiana e serrolandense de forma marginalizada, porque a quantidade de imagens de santos que são culturalmente mesclados entre as duas religiões é muito forte.

Ao observarmos a presença de colares (imagem 2 da figura 5), percebemos que são símbolos comumente utilizados nas religiões afro e não apropriados pelo uso católico. Assim, procuramos através de fontes bibliográficas o significado desses objetos que foram postos ao lado das imagens de São Cosme e São Damião, santos também sincretizados. Entretanto, as cores mescladas e a presença de outro colar marrom dificultaram para que fossem encontradas uma resposta fidedigna. Desta forma, buscamos respostas com um adepto da religião do Candomblé e questionamos quais eram os significados simbólicos dos colares encontrados:

Pelo que dá pra identificar, foi alguém que se desfez do objeto. Essas cores azuis representam Ogum. Se a gente colocar a branca, a gente pode até tratar como Oxoguiã. A verde se for na Angola, representa Ogum e se for no Keto, na minha nação, representa Oxóssi, que pode vir com aquele azulzinho bem cor do céu, bem fraquinho, mas aí tá muito mais voltado a um culto de Umbanda, por estar próximo a São Cosme e São Damião. ${ }^{7}$

São Cosme e São Damião (Ou Ibejis na tradição africana), são um dos santos que mais aparecem no local, de variadas formas e tamanhos, desde imagens de gesso à quadros de parede. Os santos possuem muitos simpatizantes e devotos, tanto nas religiões de matriz africana como na religião católica.

Para a tradição católica, São Cosme e São Damião eram irmãos gêmeos e exerciam a profissão de médicos. Eles teriam praticado o ofício sem cobrar nada pelos trabalhos, por isso, em grego são chamados de "anargiros", o que significa que não são comprados por dinheiro.

O culto a São Cosme e Damião na Bahia é concebido por diferentes concepções, que se interliga com o catolicismo popular e as religiões de matriz africana, como a umbanda e candomblé. Dada as suas conexões, em que os

\footnotetext{
7 Entrevista realizada em 7 de fevereiro de 2020.
} 
santos católicos eram irmãos gêmeos, médicos e faziam curas; e os Ibejis eram orixás também gêmeos e ligados à cura, os signos convergentes entre as duas tradições fizeram com que houvesse um imbricamento entre os santos das duas religiões de maneira muito forte, de tal modo que hoje é difícil distinguir quem é quem entre as concepções.

O culto a esses santos é bastante popular na Bahia, onde muitas pessoas fazem, anualmente, o Caruru8 ${ }^{8}$, também chamado na Bahia de "Caruru dos Santos" e/ou "Caruru dos Sete Meninos”, numa alusão sincrética aos sete santos católicos Cosme, Damião, Doú, Alabá, Crispim, Crispiniano e Talabi; (SANTOS, 2012). Em Serrolândia, além do caruru, é comum haver a distribuição de doces para as crianças. 9

A oferenda de caruru aos santos pode representar o "sacrifício, o ebó, como a forma essencial da sua comunicação com os orixás" (LIMA, 2005), pois com o donativo do caruru, do modo como o fez Iansã ao bendizer aos deuses pelo renascimento de seu filho gêmeo, Ibeji, os devotos celebram seu dia unindo as ritualísticas católicas e de influência africana. Segundo a autora, “dar o caruru é revestido socialmente de obrigatoriedade, obrigação moral do devoto com o santo.” (NASCIMENTO, 2014)

Há uma cantiga popular muito cantada em Serrolândia no dia celebrado a São Cosme e São Damião que reflete o culto velado aos orixás quando, na letra original da canção, há uma elevação às divindades africanas, mas somente as duas últimas estrofes são mais comuns de serem proclamadas entre a população:

Quando chegam de Aruanda Iansã quem manda Eles vêm e cantam auê, auê no romper da aurora Isquidim, isquidim as crianças vem assim

Lá vem Cosme e Damião vestidinho de azul Vem de dois em dois pra comer seu caruru.

\footnotetext{
${ }^{8}$ Comida ou obrigação feita à base de quiabo, azeite de dendê e camarão.

9 De acordo com Nascimento (2014) a devoção a São Cosme e Damião, "que "come" caruru, tem aura de criança, ganhou vida e se perpetuou no tempo através do catolicismo popular e doméstico. Ele se mescla de características arquetípicas de múltiplas influências, uma miscelânea de identidades, cosmologias, religiões. Segundo o autor, o banquete - caruru representa um dom, no sentido "maussiano, do "dar, receber e retribuir", sendo uma contrapartida aos benefícios recebidos." (NASCIMENTO, 2014, p.8).
} 
Figura 63 - Imagens de São Cosme e São Damião encontradas na Capela do Cemitério Municipal Anízia Carneiro de Magalhães

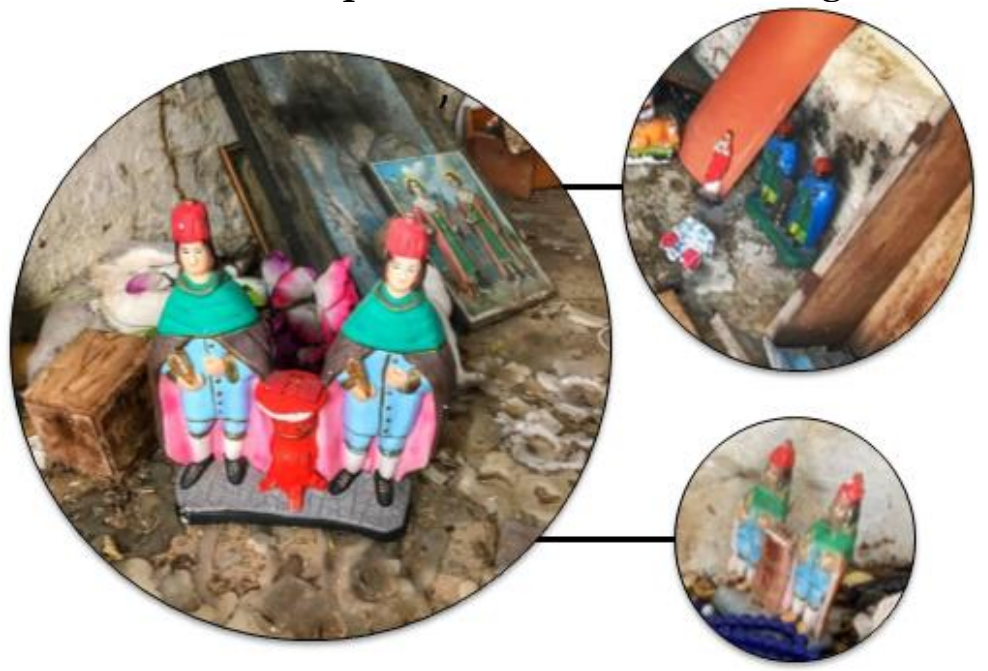

Fonte: Saldanha, 2020.

Isso se deve ao sincretismo religioso que, Segundo Ortiz apud Soares (2002, p. 51), " realiza-se quando duas tradições são colocadas em contato, de tal forma que a tradição dominante fornece o sistema de significação, escolhe e ordena os elementos da tradição subdominante". Assim, as hibridizações religiosas encontradas no cemitério católico, onde as alocações das imagens dos santos são frequentes, podem ser resultado de uma crença que foi imposta a uma adequação sociocultural.

Essas trocas resultaram em uma articulação entre as culturas brasileira e africana que reforçaram as diferenças e ligações de suas identidades. O Brasil como um todo foi contemplado por esse hibridismo cultural-religioso, se configurando como a materialização da "religiosidade de um Brasil experimentado pelas classes populares.” (ABUMANSSUR apud BRAGA, 2006, p. 308).

Essa religiosidade popular possibilitou que diferentes segmentos religiosos expressassem seus cultos nos espaços materiais e geossimbólicos das cidades, através das procissões, comemorações de santos, no pagamento de promessas e, no caso da morte, nas representações fúnebres.

Além dos santos retratados na figura 6, outras imagens coexistentes são frequentes na capela do cemitério católico, como Logunedé, sincretizando como Santo Expedito; São Benedito ou “Ossaim”, o santo protetor dos negros; Santa Bárbara, a "Iansã, Orixá dos raios e das tempestades"; Nossa Senhora da 
Conceição, a "Oxum”, orixá das águas doces, dentre outros santos católicos que são comumente justapostos pela religião de matriz africana e, muitas vezes, confundidos pelos próprios devotos.

Imagens de Jesus negro ou da Virgem Maria negra também são comuns dentro da capela, muitas vezes postas ao lado de objetos pessoais, como colares, bonecas, terços, oratórios e quadros com fotos de pessoas falecidas.

$\mathrm{Na}$ figura 7 trouxemos as representações de imagens de santos em protótipos pretos, mas que, na cultura católica, são normalmente representados pela cor branca, como Nossa Senhora das Dores e o Sagrado Coração de Jesus:

Figura 74 - Imagens de cores negras (Jesus e a Virgem Maria) encontradas na capela do Cemitério Municipal Anízia Carneiro

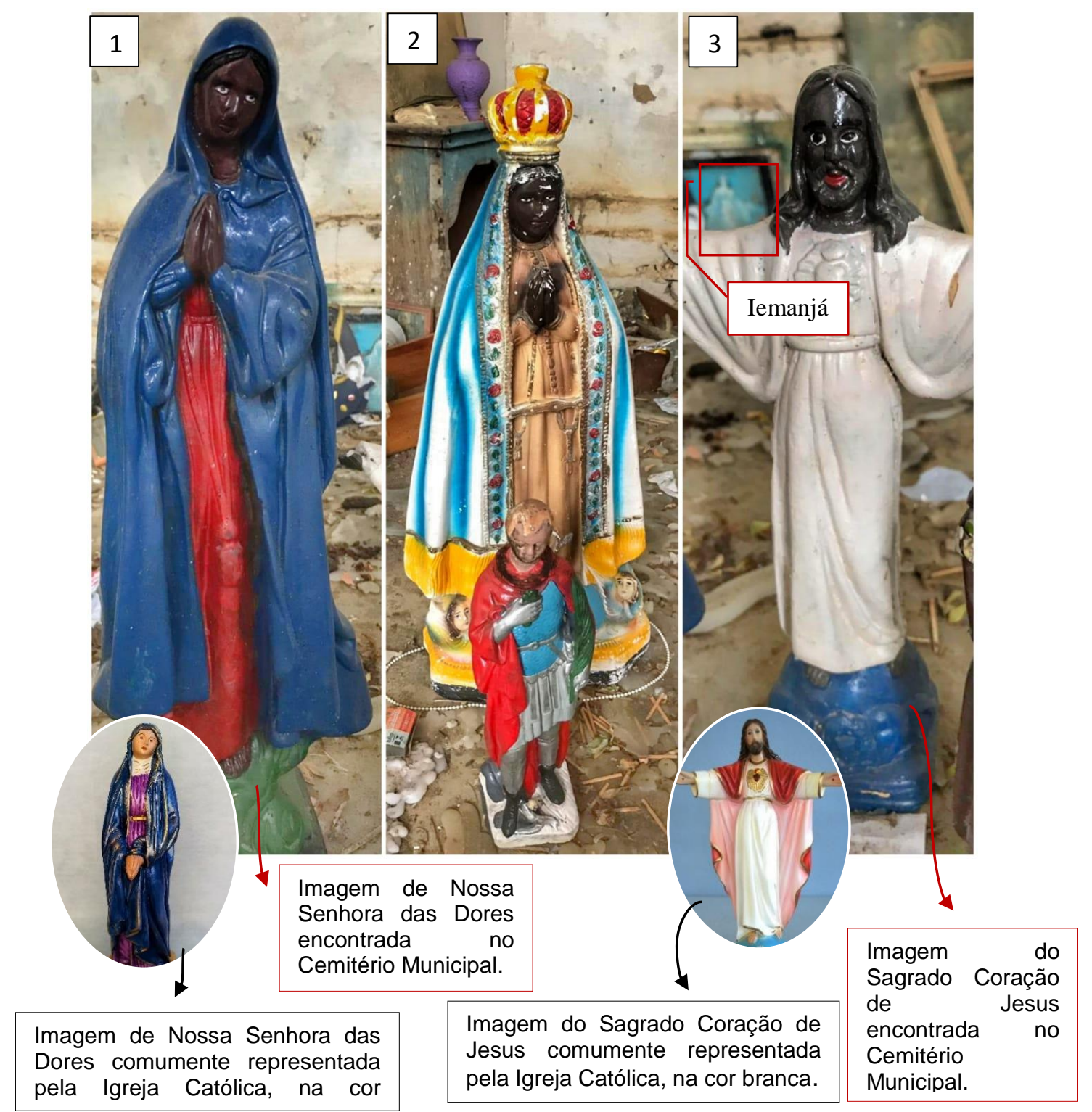

Fonte: Saldanha, 2020. 
Imagens como a de Nossa Senhora Aparecida, padroeira do Brasil (imagem 2 da figura 7) são representações que correspondem com a doutrina católica em sua cor preta por origem. No entanto, as imagens 1 (Nossa Senhora das Dores) e 3 (Sagrado Coração de Jesus), com protótipos negros não coincidem com o que é representado pela Igreja Católica, já que normalmente são reproduzidos na cor branca.

Possivelmente essas representações hibridizadas se devem às influências das artes religiosas afro-brasileiras, em que artistas negros "desenvolviam sua arte destituindo-se de seus padrões, para aperfeiçoarem-se em novas concepções, levando em consideração as religiões: candomblé e o catolicismo.” (ALMEIDA, LIMA e GAIA, 2016, p. 8.)

De acordo com o autor, os santeiros, como são chamados os artesãos que se especializaram na arte afro-brasileira, se baseiam em duas premissas para as suas representações: por um lado, pela referência histórica de transmitirem os nomes e traços dos seus orixás para os santos católicos e vice-versa; e, por outro lado, por empregarem técnicas manuais que possibilitam manter viva a memória e os saberes adquiridos pelos seus antecessores. "Nessa perspectiva, a estética dos santos, plural e multiétnica, muito tem dos traços do candomblé, sejam nas cores, nas formas, e nas atribuições ritualísticas" (ALMEIDA, LIMA e GAIA, 2016, p. 8).

Embora atualmente as religiões afro estejam mais livres e não tenham a necessidade de ocultarem ou disfarçarem suas crenças, a cultura serrolandense ainda é pautada no tradicionalismo cristão. Portanto, é difícil distinguir se as imagens na cor preta são derivadas das crenças afro-brasileiras (ainda disfarçadas) ou se são apenas significações católicas diferenciadas.

Além disso, a hibridização ritualística entre as religiões se dá de maneira tão forte que às vezes os próprios fiéis utilizam-se das duas doutrinas sem ter ciência das diferenças entre si. Para Almeida, Lima e Gaia, isso é reflexo da fusão religiosa, que faz com que o catolicismo popular e as religiões afrobrasileiras se mesclem com "as artes a elas associadas e se desenvolvam como espaço de mediação, de confluências e interpenetrações de ritos, liturgias e visões de mundo no qual o religioso e o artístico se fundem e se desdobram em múltiplas faces" (ALMEIDA, LIMA E GAIA, 2016, p. 10). Assim, os objetos, 
imagens e demais símbolos das duas religiões expressam-se mutuamente, evidenciando a indissociabilidade existente entre eles.

Desta forma, propomos duas possibilidades para a inserção da cor preta nas imagens dos santos: ou as reproduções são exclusivamente católicas e tem apenas uma especificidade de pintura diferenciada do comum, ou são imagens impregnadas de influências das religiões afro, feitas a partir dos traços do candomblé, com a ingerência das cores, formas e nas devoções ritualísticas.

Além das imagens, percebemos que o chão da capela é carregado de velas ou resto delas. Neste caso, essa expressão se traduz pela crença católica de que "o fogo impõe uma purificação necessária", (VOVELLE, 2010, p.26). No o uso das velas, percebemos que a crença se volta inteiramente ao catolicismo, porque são postas regularmente no dia de finados, dia instituído pela Igreja Católica para que se reze pelas almas. Além disso, acreditamos não ter ligação com as religiões afro porque as velas utilizadas pelo Candomblé e Umbanda tem significados diferentes de acordo às suas cores específicas, o que não encontramos no cemitério.

\section{CONSIDERAÇÕES FINAIS}

Compreendemos, a partir dos resultados deste trabalho, que os cemitérios são caminhos para se compreender como os homens se relacionam com a morte e como os simbolismos e, sobretudo, como as crenças podem ser fontes de elo entre os vivos e os mortos.

Foi possível identificar como a dimensão religiosa se materializa fortemente a partir da impregnação de elementos simbólicos fixados no ordenamento espacial do ambiente fúnebre, como é o caso dos símbolos católicos e sincréticos nos espaços cemiteriais de Serrolândia.

Quanto a esses símbolos, compreendemos que sua utilização se explica como meio de imortalizar a memória de outrem (através das lembranças) e dos símbolos, os quais simbolizam, para muitos crentes, algo sagrado, pois os mistérios - incompreensíveis e invisíveis - carregam consigo o fascínio e a representação transcendente, que limita o homem a um ser pequeno diante da morte - aqui se refere às sensações - ao imaginar a magnificência de algo maior que a si mesmo. 
Isso se dá através da experiência do sagrado nas representações da morte, pois na medida da existência, algumas sensibilidades fenomênicas são suscitadas, remetendo ao universo transcendental. A partir dessas circunstâncias, o homem busca respostas no plano sobrenatural, consagra-se e, ainda que de modo laicizado, transfere suas inquietações ao campo fúnebre, mesmo que por origem e influência cultural.

Desta forma, analisar as necrópoles em Serrolândia, além de nos fazer conhecer os aspectos relacionados à morte, nos auxiliou na compreensão dos modos como os sujeitos utilizam dos símbolos de maneira a representar as características individuais do falecido ou elevar as orações e penitências em visitas ao cemitério, a fim de estabelecer um elo entre os vivos e os mortos.

\section{REFERÊNCIAS}

ARAÚJO, T. N. H. Hermenêutica e cemitérios: um olhar sobre o cemitério da Santa Casa em Porto Alegre. Ciencias Sociales Y Religión/Ciências Sociais e Religião, Porto Alegre, ano 16, n.20, p.82-95, jan-jun de 2014.

ARIÈS, P. Sobre a História da Morte no Ocidente desde a Idade Média. $2^{\mathrm{a}}$ ed. Lisboa: Editorial Teorema, 1989.

ALMEIDA, A. D. S; LIMA, M. L; GAIA, R. V. Santos e orixás: sincretismo, estética e arte afro-brasileira na estatuária da Coleção Perseverança. Revista Crítica Histórica. Ano VII, $\mathrm{n}^{0}$ 14, dezembro/2016.

BARBOZA, V. M. Sociedade dos Vivos X Cidades dos Mortos: A Visão da Morte na Sociedade Erechinense. PERSPECTIVA, Erechim. v.37, n.140, p. 125-137, dezembro/2013.

BELLOMO H. R. A Arte Funerária. In: BELLOMO, H.R. (Org.) Cemitérios do Rio Grande do Sul - Arte, Sociedade e Ideologia. Porto Alegre: EDIPUCRS, 2000.

BRAGA, E.; GIUDICE, P. O grande dia de padre Eustáquio: após meio século de espera, fiéis se reúnem no Mineirão para assistir à cerimônia de beatificação do pároco. O Tempo. Belo Horizonte, 15 jun. 2006.

CASCUDO, L. C. Religião no povo. In. Superstição no Brasil, $4^{a}$ edição. São Paulo: Global, 2001.

CASSIRER, E. A filosofia das formas simbólicas. O pensamento mítico. Martins Fontes: São Paulo, 2004 [1925].

CATROGA, F. O céu da memória: cemitério romântico e culto cívico dos mortos. Coimbra: Livraria Minerva Editora, 1999. 
CERVEIRA, S. A. Protestantismo Tupiniquim, Modernidade e Democracia: limites e tensões da(s) identidade(s) evangélica(s) no Brasil contemporâneo. Revista de Estudos da Religião março / 2008 / pp. 27-53 ISSN 1677-1222.

FÉLIX, L. O. Política, memória e esquecimento. In: Tedesco, João Carlos. Usos de memórias: política, educação e identidade. Passo Fundo: UPF Editora, 2002.

GIACOIA JR., O. A visão da morte ao longo do tempo. Simpósio Morte: Valores e Dimensões. Revista Medicina, Ribeirão Preto, 2005; 38(1): p. 13-19.

GIL FILHO, S. F. Igreja Católica Romana: Fronteiras do Discurso \& Territorialidade do Sagrado. Tese (Doutorado em História). Setor de Ciências Humanas, Letras e Artes, Universidade Federal do Paraná, Curitiba. 2002.

IBGE - INSTITUTO BRASILEIRO DE GEOGRAFIA E ESTATÍSTICA, 2010. Resultado dos Dados Preliminares do Censo - 2010. Disponível em: www.ibge.gov.br. Acesso em 22 de janeiro de 2019.

LE GOFF, J. História e Memória. São Paulo, Editora da Unicamp, 1996.

LIMA, V. C. Cosme e Damião: o culto aos santos gêmeos no Brasil e na África. Salvador: Corrupio, 2005.

MERLEAU-PONTY, M. Fenomenología de la Perceptión. Buenos Aires: Planeta-Agostini, 1994.

NASCIMENTO, L. M. Vozes de Fé e Devoção: uma Etnografia do Culto Doméstico a Cosme e Damião Em Cachoeira/Bahia. Revista Olhares Sociais. / PPGCS / UFRB, Vol. 03. No. 02/ 2014.

PIACESK, T. R; BELLOMO, H. R. Pesquisa cemiterial no estado de Goiás. Porto Alegre: s.n., 2006.

PIMENTEL, R.R. Matriz de Nossa Senhora da Conceição da Serra-ES: Igreja e Religiosidade no Contexto da Romanização Católica (1880-1916). Universidade Federal do Espírito Santo. Dissertação (Mestrado em Artes). Vitória, 2012.

RIOS JÚNIOR, J. S. Narrativas de Fé e outras histórias dos Batistas em Serrolândia. Universidade do Estado da Bahia. Dissertação (Mestrado em História) Santo Antônio de Jesus, 2012.

RIVERA, D, P, B. O demônio e o protestantismo no mundo em desencantamento. Estudos de Religião, Ano XXI, n. 33, 42-58, jul/dez 2007.

ROSENDAHL, Z. Espaço e religião: uma abordagem geográfica. Rio de Janeiro: UERJ, NEPEC. 1996. 
SANTOS, K. A. C. Os Portais, o Baú, o Cavalo e o Farol: a espetacularidade na festa de São Cosme e São Damião no Terreiro de Mina Dois Irmãos.

Dissertação (Mestrado em Artes). UFPA, Belém, 2012.

SOARES, A. M. L. Sincretismo afro-católico no Brasil: lições de um povo em exílio. Revista de Estudos da Religião. No 3 / 2002.

URBAIN, J. D. A sociedade de conservação? Estudo semiológico dos cemitérios do Ocidente. Paris: ayot, 1978.

VOVELLE, M. As almas do purgatório. São Paulo. UNESP, 2010.

Recebido em 26 de junho de 2020

Aceito em 27 de novembro de 2020 